\title{
City-State (Medina) and Its Implementation in the Republic of Indonesia
}

\author{
Agus Nurhakim 1 \\ ${ }^{1}$ Nurul Fikri Institut Lembang, West Jawa, Indonesia \\ Email:akh_hakim@yahoo.com
}

\begin{abstract}
:
This article describes on how the principle of the Islamic State concerned with Indonesia as a nation state. State elements theory explains that the country is composed of three elements such as the region, the people, and the government as well as the sovereignity. By using the literature study, this article found that the Prophet Muhammad is a leader who always carries his reign by implementing the principles of Islam as well. Among the principles of the state in Islamic perspective consists of the trust, consultation, fairness, freedom, and equality. Relating to this reason, the Indonesian state is seen as the state of law because it refers to the 1945 Indonesia Constitution (UUD 1945) and Pancasila. Shortly, Indonesia is in need of having the people who has the responsibility and trusted in maintaining this country.
\end{abstract}

Keywords: City State, Medina, Republic of Indonesia

\section{A. INTRODUCTION}

There is a difference of opinion on whether the medina is included in a country or not. That difference stems from the theory of the relationship occurred between religion and the State.

Munawir Sjadzali explains that there are three streams of Islam and constitutional relationship. First, the flow of which holds that Islam is not merely a religion in the sense of the west, which is only about the relationship between man and God, whereas Islam is a religion that is perfect and complete with rules for all aspects of human life, including life of the state. Second, the flow of which holds that Islam is a religion in the western sense has nothing to do with affairs of state. Third, the flow of which reject the idea that Islam is a religion which is complete and that in Islam there is a state system. But this flow also rejects the notion that Islam is a religion that governs the relationship between man and God. This flow is of the opinion that in Islam there is no constitutional system, but there is a set of values of ethics for the life of the state. (Sjadzali, 1991:1-2)

Muhammad Hari Zamharir also said that there are three models in the relationship between religion and the State, namely: First, the secular model, namely in terms of the legitimacy of power that no longer correspond to the political ethics of the modern State. Second, complementarity models, namely the relationship between religion and the state as related to each other. Third, integrative models, namely the State is a tool to achieve the objectives of religion. (Zamharir, 2004: 77-84)

In accordance with the elements of the establishment of a state, then in this case the Medina included into the State, namely: first, their territory (limit certain regions), ie Medina; second, the 
existence of the people, that the various groups of large and small; and third, a sovereign government, that Muhammad is generally adhered to and obeyed by the citizens of Medina and there is no other authority that she is employed. (Sukardja, 2012: 124-125) It is also in accordance with the opinion of Al-Farabi are in permaslahan country, he is drawn to the State medina (citystate), so that the city-state is the best state than the nation-state or regional State (Sofyan, 2012: 259)

State of the Medina, the Prophet did not separate between religion and the State. In addition, the concept of the Medina constitution which included covers of freedom of religion among the people of Medina as evidence that union was.

The existence of these differences occur because even though Islam is a universal religion whose teachings contain the basic principles of life including politics and the state, but the reality has occurred that Islam explicitly does not provide provisions on how to shape and concept of the State. (Salim, 2002: 286) In fact, the term the State was not mentioned in the Qur'an, but in it there are verses that indicate that Allah SWT also provides general concepts about the government and the State in the form of basic principles in society and state which is described as the principle of power is a trust, the principle of fairness, the principle of equality, the principle of freedom, and the principles of these meetings. (Syarif, 2003: 11) The principles are only made possible by the existence of a state.

\section{B. METHODS}

This article uses the literature study as a method to understand how the principles of the Medina state are linked to the Indonesian context as a nation state.

\section{RESULT AND DISCUSSIONS}

\section{Definition of The State}

Plato define the State as a body that is constantly developed, evolved and consists of those (individuals) that arise or exist because each of that person alone can not meet the needs and desires of diverse, which caused them to have to work together to meet their common interest. Unity is then referred to the public or State (Busrah, 2011: 21). As Aristotle define the State as an entity that has a specific purpose. According to the State occurred due to the incorporation of families into a group, then the groups merged into the village, and so on until there became to be State. (Soehino, 2008: 24).

R. Kranenburg also said that the State was essentially a power organization created by a group of men. So in this case, according to Kranenburg first there must be a group of people who have the awareness to establish an organization with the purpose of maintaining the interests of the group. (Busrah, 2011: 22-23) Meanwhile, according to Karl Marx, the State is an incarnation than the contradictions of economic power. So he said, a country will be destroyed or disappear by itself if in the community there are no class differences and economic contradictions. (Soehino, 2008: 133)

Furthermore, Muhammad Yusuf Musa define the State as a group of people in a particular climate that is sovereign and in which there are rules. (Hamd, 2000: 39) Suwisri also define the State as a collection of people who live continuously in certain areas in which there are people who provides legal and the person convicted. (Hamd, 2000: 40) 
Based on these definitions can be concluded that the State is a continuation of the will of a group of people in a given area interacting with each other in accordance with rules made in order to meet and enhance all the necessities of life.

Based on these definitions anyway, then Medina can be categorized as a country with some of the following reasons: first, it meets state elements, namely: their regions, their people and their sovereign governments; (Busroh, 2011: 75) The second, after the Prophet Muhammad arrived in Medina, he performed three strategic areas, namely: building a mosque as a place of deliberation, unite in friendship between the Muhajirin and the Anshar as a merger of group effort and fulfillment, and the cooperation and agreement with the Jews of Medina; (Katsir, 1402, 118-120) and third, the third case, the Medina community can meet its goals.

By its nature, the State of Medina is a Muslim country as it implements Islamic laws and state security are under the guarantee of the Muslims. (Ramadlan, 2003: 7) This is similar to the definition of Mahmud Abdul Karim Hasan of the Islamic State, namely the political institutions which implement practical application of Islam to establish the religion of Islam is perfect. (Hasan, 2003: 127)

Hamd bin Muhammad also defines the Islamic state as a collection of people Muslim and nonMuslim (kāfir dhimmī) who live in certain areas and subject to the rules of Islam. (Hamd, 2000: 56)

\section{The Purpose and Function of The State}

The main purpose of the State is in the interest of the order of a State, so that there is not a country that does not have a purpose. Shang Yang (a minister from one of the Chinese empire) argue that the State is to establish power. For the formation of the power he held a sharp distinction between the State and the people, where the difference is interpreted as the opposite one to the other. Shang Yang said that if people want to make the country strong and absolute power, then he should make people weak and poor, otherwise if people want to create a strong and prosperous people, then he should make the country weak. (Kusnardi and Bintan, 2008: 7374)

Dante aspires about the purpose of the State that all countries in the world to be the power of a king. Dante intended destination not to gain absolute power, but by uniting all nations under the power to bring the progress of mankind throughout the world, especially in achieving happiness in life is the highest. (Kusnardi and Bintan, 2008: 76)

In the law of political Islam, the state religion serves as guardian and regulator of the world. (alMawardi, 1989: 3)

As in Indonesia, the issue of the proclamation of independence, namely in the preamble of the 1945 Constitution, the State mentioned the following objectives:

"To promote the general welfare, educating the nation and participate in the establishment of world order based on freedom, lasting peace and social justice." (Sukardja, 2012: 265)

The functions of the State, that is the duty of the State to what state it is held. In theory, there are five state functions understood, that the function of the State in the sixteenth century in France, the function of the State according to John Locke, Montesquieu according to the State function, the function of the State according to Van Vollen Hoven, and the function of the State according to 
Goodnow. (Busroh, 2011: 22-23)

In the sixteenth century was first introduced in France and is known with five functions: the function of diplomatic serves as a liaison anatar State, function defencie to address the issue of security and the national defense, the function Financiè providing financial state, the function justicie to maintain order and discord among citizens, and function Policie to take care of the interests of the State which is not under the authority of other departments (the state department, defense department, finance department, the justice department and the ministry of interior). (Busroh, 2011: 83-84) However, historically these functions created to meet the needs of the government at that time still a dictator.

The functions of the State, according to John Locke, the function of the State is divided into three parts, namely the function of the legislative duty to make laws, the executive functions assigned to carry out the regulation and function of federative charge of foreign affairs and matters of war and peace. (Kusnardi and Bintan, 2008: 221-222)

According to the theory of John Locke, a hearing function is included executive duties. The theory is then refined into three functions of each of these functions separately and implemented by the institution separately anyway.

In contrast to Montesquieu which found that the State function is the function of the legislature to make laws, the executive functions that implement the law, and judicial functions that oversee that all rules monitored. (Busroh, 2011: 83-84) Montesquieu enter federative function to the executive function, and the function of judge be a function of its own. It can be understood that the purpose of Montesquieu is for political freedom or the protection of human rights can only be achieved with the power to hear a stand-alone.

In addition to these theories, still known another theory is the theory of Van Vollen Hoven, which discusses the function of the State as the above theories. According to Van Vollen Hoven function that State there are four, namely, regeling function that serves to make the rules, bestuur to move government functions, function rechtspraak to prosecute, and functions for order and security politie. (Kusnardi and Bintan, 2008: 222)

From the above description indicates that the function of the State is always changing. And from the above description, the State carry out its function, which is carrying out policing (law and order) that serves as the country's stability in order to stimulate the smooth process of development. When stability has been achieved, then the development process is determined by a combination and balance between the four requirements. First, the leadership of the political community must have a sense of great responsibility which is reflected in the dedication to the public interest and the commitment to live up to the basic problems in people's lives. Second, leaders must have a political perception that is wide and deep. Third, the professional expertise and technical skills in various fields. Fourth, the basis framwork for effective power. (Kusnardi and Bintan, 2008: 222)

In contrast to the function of the Islamic State, Islamic State has a function that has not changed is to execute the laws of Shari'a and Islamic missionary.

\section{Forms of the State}

The thinkers do not have an agreement on the definition of the form of the State, even among those still confuse the form of the State with the form of government. Some thinkers specify the 
nature of the State as a kingdom or a republic, others interpret the form of the State as a form of unitary state or a federal state. (Kusnardi and Bintan , 2008: 159) Otto Koellreutter added a form of third, namely autoritarenfuhrestaat, the head of state appointed by the mind to the ruling referred to as 'der Gedanken der Staatsautoritat'. (Busroh, 2011: 59-60).

Aristotle put forward three kinds of state he shared into an ideal shape and form of deterioration, namely: the ideal form of the State is the Monarchy, Politea, and Aristocracy. And form slump is Tyranny, oligarchy, Plutocracy, and Democracy.

The shape of the state in the Middle Ages there are two kinds, namely republic and empire. It's the kind described by Machiavelli who said that the State was otherwise kingdom (principal) is certainly republic (republica). (Moh. Kusnardi and Bintan R, 2008: 164).

From the descriptions above, has not been seen on the actual form of the State. Therefore, thinkers seeking formulation forms of state closer to reality, then in contemporary times appeared streams based on the actual form of the State. Streams are: (1) understand the problem of combining state form with a form of government, (2) understand that discusses the state form into two groups, namely democracy or dictatorship, and (3) to understand that trying to solve the country shape with measure- size/provisions that already exist. (Moh. Kusnardi and Bintan R, 2008: 165-166).

In line with this, how is the form of the State in Islam? According to Muhammad Haikal, Islam never specify the system and that the raw form of the State must be recognized by all Muslims. Islam just put the basic principles that can be used as guidelines in determining the system of government that evolved throughout history, such as equality, consultation, brotherhood, and freedom. (Haikal, 1983, 29-44) Therefore, he argued that Muslims are free to practice the system of government that somehow, as long as the system is running the principle of consultation that adhering to the ethical and moral values taught by Islam. (Sjadzali, 1995: 188).

In this regard, Ibn Taimiyyah himself argued that Islam did not set a standard form of government. The historical background of Al-Khulafâ' Ar-Râsyidûn only an accidental, not instance or example of civic life. Therefore, constitutional experts have the right to plan their own form of government for not deviate from the intent and purpose of the Shari'a. (Jindan, 1995: 36).

The rationale for this is what seems to cause changes in the form of State in the history of Muslims stage change with the times. For example, at the time of the Prophet Muhammad patterned theocratic State, at the time of Al-Khulafâ' Ar-Râsyidûn patterned and democratic republic, and at the time of the Umayyad dynasty and the Abbasids dynasty patterned monarchy.

In line with this, the basic principles of Islamic countries should remain present in all forms of the state. Among these principles are as follows: (1) the principle of power as Amanah (QS. An-Nisâ': 58); (2) the principles of justice (QS. An-Nisâ': 58 ); (3) the principle of equal political rights (alBukhari, 1422: number 3166); (4) the principle of consultation (QS. As-Syûrâ: 38); and the principle of freedom (QS. Al-Isrâ': 70).

\section{Principles of Islamic Countries at the time of the Prophet Muhammad and the implemetations in Indonesia}

Every decision taken, the Prophet Muhammad always conduct deliberations with his companions. For example, when there will be a war of Uhud and war Khandak. (Syafiyyurrahman, 2009: 339- 
240) So also with the principles of justice, at the time of the Prophet Muhammad can be seen in an event when a child dignitary named Fatima bint Asad steal the Prophet Muhammad still carry out the punishment for the. (al-Bukhari, 1422: number 6787) More about the application of the principle of justice and the principle of freedom at the time of the Prophet, it can be seen in the constitution of Medina. (Ahmad Sukardja, 2012: 81-88) On justice, the Constitution of Medina formulate that a person is not responsible for errors made allies. (Ahmad, 1973: 28)

As for the principle of equality, it is very close to justice. How Rasulullah SAW implement the principle of equal education can be seen also from the case Fatima bint Asad and the constitution of Madinah. In this principle also no advantages over others unless someone virtue of piety.

Said Ramadan Al-Buthi, as written by Muhammad Tahir Azhari argues that there are three things in the Constitution of Medina in conjunction with the equation, namely: First, it has created a kontelasi socio-political in the State of Medina consisting of people Islamic and non-Islamic (Jewish). Secondly, the position of the Jews set out clearly in the Constitution of Medina. Third, the guarantee of equality both protection and security for the people of Islam as well as for those nonMuslims. (Azhari, 2003: 164-165)

From the description it can also be said that the Islamic State is the State who would love unity. All the good citizens of different skin or different religions, all of which exist in the territory of Islam united with the Islamic government.

In line with this, the Prophet Muhammad split the state duties as governor (wâli), judges (qâdli), secretary (kâtib), and zakat ('âmil), he never gave the task to a person unless the person is able to maintain and implement.

In the opening match of the 1945 Constitution the formulation of Pancasila as follows:

"... Then drafted the independence of the Indonesian nation was in a Basic Law the State of Indonesia, which is formed in an arrangement of the Republic of Indonesia the sovereignty of the people with based on: on God, humanity just and civilized, the unity of Indonesia, democracy led by the inner wisdom of deliberations/representatives, as well as by fostering a social justice for all Indonesian people." (Salam, 1988: 117)

From the opening of the 1945 Constitution, Pancasila consists of five basic (sila), namely: (1) Belief in God Almighty; (2) a just and civilized humanity; (3) Unity of Indonesia; (4) democracy led by the wisdom in concultative representative; (5) Justice for all Indonesian people. (http://id.wikipedia.org/wiki/Pancasila, 10 January 2014)

In the first principle, namely 'Almighty God', then Indonesia recognize and believe in the existence of God. God Almighty is the cause of human existence and the universe and all living and life in it. This basic freedom that guarantees each citizen Indonesia to embrace their religion and worship according to agamanyanya respectively. It is stated in Article 29 UUD 1945 which reads: "The State is based on God". (http://www.dpr.go.id/id/uu-dan-ruu/uud45, 16 January 2014).

Seen from the point of Islamic law, it is identical to the first principle of monotheism which is the core/foundation of the teachings of Islam. However, in terms of the other first principle means that Islamic teachings given tolerance, freedom and opportunity as possible for followers of other religions to carry out the teachings of their respective religions. (Azhari, 2003: 164-195). 
Muhammad Natsir said Indonesia is an Islamic country by the fact that Islam is a religion for the people of Indonesia, although the Constitution of the Republic of Indonesia is not declared as State religion. But Indonesia does not separate religion from the state. Indonesia puts trust in God Almighty as the first principle of Pancasila adopted as the foundation of the spiritual, moral, and ethics for state and nation. (Sjadzali, 1993: 194-195) Then Muhammad Natsir argued that Pancasila is a statement of intent and ideals of virtue that must be implemented in the State and the nation. Therefore, if designated by the precepts on God it was confirmed that a man would not be able to start his life to benevolence and virtue before he can awake and gave herself to God Almighty, then how the Quran would be contrary to the principle that , However, Muhammad Natsir added another as if the precepts on God it was only a slogan for those whose soul is actually contrary to religion.

Second "just and civilized humanity", described by C.S.T. Kansil that human beings as God's creatures all have the status and rights of the same, because God does not distinguish only between human beings with one another. Therefore, it is not justified human one man dominate the other, or one nation possess the other. (Kansil, 2001: 94-95) Just and civilized humanity also means upholding human values, likes to do activities such as helping humanity, to meet the needs of others, and the brave stand for truth and justice.

Third principle "unity of Indonesia", meaning that the basis of nationality meant the entire Indonesian nation must foster close union between fellow citizens, without distinction of race or class. The principle of nationality was a close bond between groups and tribes. (Kansil, 2001: 98).

Fourthly, "populist, led by the inner wisdom of deliberations representation", this principle indicates that the Indonesian state adopts democracy, it means the power to govern the country and the people are in the hands of all the people.

Fourthly, it contains implies that the people in the running of his power, carried out through a representative. The decisions taken by the representatives was done through consultation led by common sense and a sense of responsibility both to God Almighty and to the people they represent.

Five precepts of "social justice for all Indonesian people", meaning that every Indonesian people receive fair treatment in the areas of legal, political, economic, social, cultural, and defense and security. (Kansil, 2001: 109).

All these precepts can be found similarities with the principles of rule of law (Islamic nomocracy) such as justice, consultation, equality, and freedom.

In line with this, the main principles contained in such deliberation of Islamic democracy, justice, and equality and constitutionally either explicitly or implicitly can be read in the 1945 Constitution Democracy itself is a doctrine or a secular political system that sovereignty belongs to the people or 'sovereignty' that government of the people, by the people and for the people. Theologically, the Indonesian Muslim intellectuals addressing democracy based on the concept of deliberation in the Qur'an, the practice of the Prophet Muhammad and al-Khulafâ' ar-Râsyidûn. They have their own views about democracy, not only declared their opposition to liberal democracy or socialist democracy without reason or accept the concept of democracy with the record still acknowledge God's sovereignty in tanga, in other words accept democracy but basically states that sovereignty belongs to God instead of people's sovereignty. (Hasbi, 2001: 146). 
Democracy according to the 1945 Indonesia Constitution is Pancasila democracy. Each precepts, including the first principle "Almighty God" is the basis for democracy in Indonesia. In a democracy, the people and the authorities are bound by the values of Pancasila. Therefore, the State does not separate religion from state affairs, so that democracy was not separated from religious values. (Sukardja, 2012: 132).

The principle of consultation is expressly formulated in the fourth principle of Pancasila. The application of this principle in the State of Indonesia such as in decision making through the House of Representatives (DPR) and the People's Consultative Assembly (MPR), which tends to always put unanimity (consensus) rather than majority voting formulas as applied in western democracies. However, in this case to be found in common if the power groups or political parties enjoy rather than prioritizing consensus opinion. (Hazairin, 1973: 22).

In a deliberation, the difference is a natural thing, and it should be upheld for all parties entitled to express their opinions. Moreover, to do with criticism and advice to leaders is one of the forms of participation of the people.

The principle of consultation can not stand alone without the support of other principles such as the principle of justice and equality. In the implementation of the principle of consultation, should any individual have to be fair.

Basically, the principles contained in the 1945 Constitution, such as the principle of justice that has been transformed into the 1945 opening through the second principle is "just and civilized humanity" and the five precepts of "social justice for all Indonesian people". The purpose of the second principle was to put a man in accordance with the dignity as God's creatures. The principle of fairness contained in the second principle is also a philosophical view of Indonesian people who are not able to get the oppression of man by another man, both physically and spiritually, or by our own people nor by other nations. (Azhari, 1992: 150).

With the second principle was also reflected in a rigorous manner the Indonesian Nation of anticolonialism for occupation incompatible with peri peri humanity and justice. Moreover, from the point of law, the implementation of one of the basic principles of the Republic of Indonesia is implementing one of the basic principles of the rule of law. And Indonesia is a country that is based on the law, then everything is there a procedure and must fulfill the legal procedures.

The implementation of the principle of justice will depend on the administrators (Walâyat), such as judges, police, prosecutors, and legal advisors. This is because they play a big role in implement the principles of justice as contained in the second principle. In addition, the implementation of the principle of justice in the State of Indonesia is not only in the field of the judiciary, but also in the field of executive and legislative power. Each of the resulting policy should be based on the second principle of Pancasila. Therefore, any decision must not contradict the second principle.

In connection with this, in nomocracy Islam, people have the right to disobey any law / policy is unfair and contrary to the Shari'a.

The principles of equality and freedom are both firmly secured in the Act of 1945 through the opening "Behold, freedom is the right of every nation, and therefore, the penajajahan him over the world should be abolished because it does not correspond to humanity and peri kedilan". (Salam, 1988: 152). 
The statement implies that everyone has equality in law. In Article 27 UUD 1945 expressly formulated as follows:

"All citizens are equal before the law and government and shall abide by the law and the government without any exception." (http://www.dpr.go.id/id/uu-dan-ruu/uud45, 16 January 2014).

The formula has meaning that all Indonesian citizens have the legal equality and have the same rights before the government. Thus, the State Indonesia there should be no discrimination against citizens.

Therefore, as has been the authors explain that the implementation of these principles will be implemented properly if manusiannya especially the administrators understand and implement exactly what is contained in it. And from that understanding, then the terms of this, we can find some similarities between the principles of Islam with the laws of Pancasila in Indonesia.

\section{CONCLUSION}

Based on the result of research and discussion:

Muhammad SAW always implement the rule by implementing the principles of Islam well. For example the principle of consultation, which before the war he always held a consultation with his companions. In addition, he also always uphold justice in the law, as well as cases of theft committed by one of the tribe of Bani Makhzum. He SAW also always raised and sent a man according to his ability. He never raised or send a friend while the friend does not have the ability on the matter. Because indeed true leadership or power is a trust that must be maintained and implemented as well as possible. Similarly, the principle of justice and the principles of equality, when there are cases of theft committed by one of the people of Bani Makhzum, he still implement hadd punishment even though the thief was one of the nobility. He SAW considers cooperation between people of high standing with the people who is a minor in enforcement.

In connection with this, Indonesian is a state law because it refers to the 1945 Indonesia Constitution (UUD 1945) and Pancasila, which is the foundation of the State. When viewed from the grains and the philosophy of Pancasila and the 1945 Indonesia Constitution, Indonesia is already nearing the principles of the rule of law such as the principles of justice, the principle of equality, the principle of freedom. In this case, the concept of rule of law in Indonesia called Pancasila state law. So is the purpose of the State of Indonesia, as stated in the preamble of the 1945 Indonesia Constitution which, according to the author, these goals do not conflict with the law. Needed people who have the responsible and trustworthy in running a country. 


\section{References}

Ahmad, Zainal Abidin. (1973). "Piagam Nabi Muhammad SAW: Konstitusi Negara Tertulis Yang Pertama”, Jakarta: Bulan Bintang.

Azhari, Muhammad Tahir. (2003). "Negara Hukum; Suatu Studi tentang Prinsip-prinsipnya Dilihat dari segi hukum Islam, Implementasinya pada Periode Negara Madinah dan Masa Kini”, Jakarta: Kencana.

Busroh, Abu Daud. (2011). "IImu Negara”, Jakarta: Bumi Aksara.

Haikal, Muhammad Husein. (1983). "Al-Hukûmah Al-Islâmiyyah", Mesir: Dâr Al-Ma'ârif.

Hasan, Mahmud Abdul Karim. (2003). "Metode Perubahan Sosial Politik”, Jakarta: PSKII Press.

Hasbi, Artani. (2001). "Musyawarah dan Demokrasi”, Jakarta: Gaya Media Pratama.

http://id.wikipedia.org/wiki/Pancasila.

http://www.dpr.go.id/id/uu-dan-ruu/uud45.

Isma'il, Muhammad bin. (1422 H). "Shahih Al-Bukhâri”, T.tp: Dar Thuq An-Najah.

Jindan, Khalid Ibrahim. (1995). "Teori Politik Islam: Telaah Kritis Ibnu Taimiyyah Tentang Pemerintahan Islam", Surabaya: Risalah Gusti.

Kansil, C.S.T. (2001). "IImu Negara Umum dan Indonesia”, Jakarta: PT Pradnya Paramita.

Katsir, Abu al-Fida' Isma'il bin. (1402 H-1403 H). "al-Fushûl fî Sîrah ar-Rasûl Sallallâhu 'Alaihi Wa Sallam”, Dimasyq: Mu'assasah 'Ulûm al-Qur'ân,.

Kusnardi Moh. dan Saragih, Bintan R. (2008). “IImu Negara”, Jakarta: Gaya Media Pratama, 2008.

Muhammad, Hamd bin. (2000). "Ârâ' Ibn Taimiyyah fî Al-Hukmi wa Al-Idârah", Riyadh, Dâr AlAlbâb.

Ramadlan, Syamsuddin. (2003). "Menegakkan kembali Khilafah Islamiyyah", Jakarta: Pustaka Panji Mas.

Salam, Burhanuddin. (1988). Filsafat Pancasilaisme, Jakarta: PT. Bina Aksara.

Salim, Abdul Mu'in. (2002). "Konsepsi Kekuasaan Politik Dalam Al-Qur’an”, Jakarta: PT. Raja Grafindo Persada.

Sjadzali, Munawwir. (1995). "Islam dan Tata Negara”, Jakarta: UI Press.

Soehino. (2008). "IImu Negara”, Yogyakarta: Liberty.

Sofyan, Ayi. (2012). "Etika Politik Islam”, Bandung: Pustaka Setia. 
Sukardja, Ahmad. (2012). "Piagam Madinah dan Undang-Undang Dasar 1945: Kajian Perbandingan Tentang Dasar-dasar Hidup bersama Masyarakat yang Majemuk", Jakarta: Sinar Grafika.

Syafiyyurrahman. (2009). "Ar-Rahiqul Makhtum: Bahtsun fi As-Siroh An-Nabawiyyah 'ala Shahibina Afdhal As-Shalat wa As-Salam", terj. Kathur Suhardi, Jakarta: Pustaka AlKautsar, 2009.

Syarif, Mujar Ibnu. (2003). "Hak-hak Politik Minoritas Non-Muslim dalam Komunitas Islam", Bandung: Penerbit Angkasa.

Zamharir, Muhammad Hari. (2004). "Agama dan Negara; Analisis Kritis Pemikiran Nurchalis Majid", Jakarta: Raja Grafindo Persada. 
City-State (Medina) and Its Implementation in the Republic of Indonesia 